\title{
References
}

Thomsen, H. H. \& Madsen, P. S. 1985: Radio ekko målinger af Indlandsisens rand i Disko Bugt området 1984. Rapp. Gronlands geol. Unders. Gletscher-hydrol. Meddr. 85/1, 20 pp.

Thorning, L. 1985: Determination of ice thickness by magnetic methods at Nordbogletscher, South Greenland. Rapp. Grønlands geol. Unders. 125, 112-114.

\section{Fourth year of glaciological field work at Tasersiaq and Qapiarfiup sermia, West Greenland}

\author{
Ole B. Olesen
}

As part of the GGU programme for the regional mapping of the hydroelectric potential of West Greenland, glaciological and climatological investigations were continued at 'Amitsulôq' ice cap in 1985, while only glaciological measurements were made at Qapiarfiup sermia. The field programme at Qapiarfiup sermia was originally started in March 1981, whereas the permanent field station near 'Amitsulôq' ice cap (fig. 1) was first established in August of the same year. Brief reports of the work have been given by Olesen (1982), Olesen \& Andreasen (1983), and Olesen (1985).

\section{Glaciological field work}

The field work in 1985 started with measurements of the winter snow accumulations on Qapiarfiup sermia on 22nd May. As the winter of 1984-85 was very mild in West Greenland and spring came early, melting had already set in. As a result it was only at the uppermost snow pits that the $0^{\circ} \mathrm{C}$ horizon had not yet penetrated to the bottom of the snow pack. Based on the state of the snow pack (density and wetness) and the trends of accumulation curves for former years, it is believed that only insignificant amounts of snow had disappeared by this time. Qapiarfiup sermia was visited again on 3rd September when the summer balance was measured.

At 'Amitsulôq' ice cap winter balance measurements started on 28th May. On the lower parts of the ice cap it was evident that some runoff had already taken place so that unfortunately the winter balance for this year is incomplete for some areas. On the small glacier tongue near the field station (location 951 on fig. 1) a 'stake farm' consisting of five stakes positioned at the corners and centre of an approximately $14 \mathrm{~m}$ square was erected. During the summer stake readings were taken every day at all five stakes. The remainder of the stakes on the ice cap were visited at irregular intervals for determination of transient balances and possible redrillings. Positions of some of the stakes were measured by intersection from fixed points on bedrock on 14th July and as in previous years the position of the glacier tongue near the camp was tape measured from markers in front of it. 


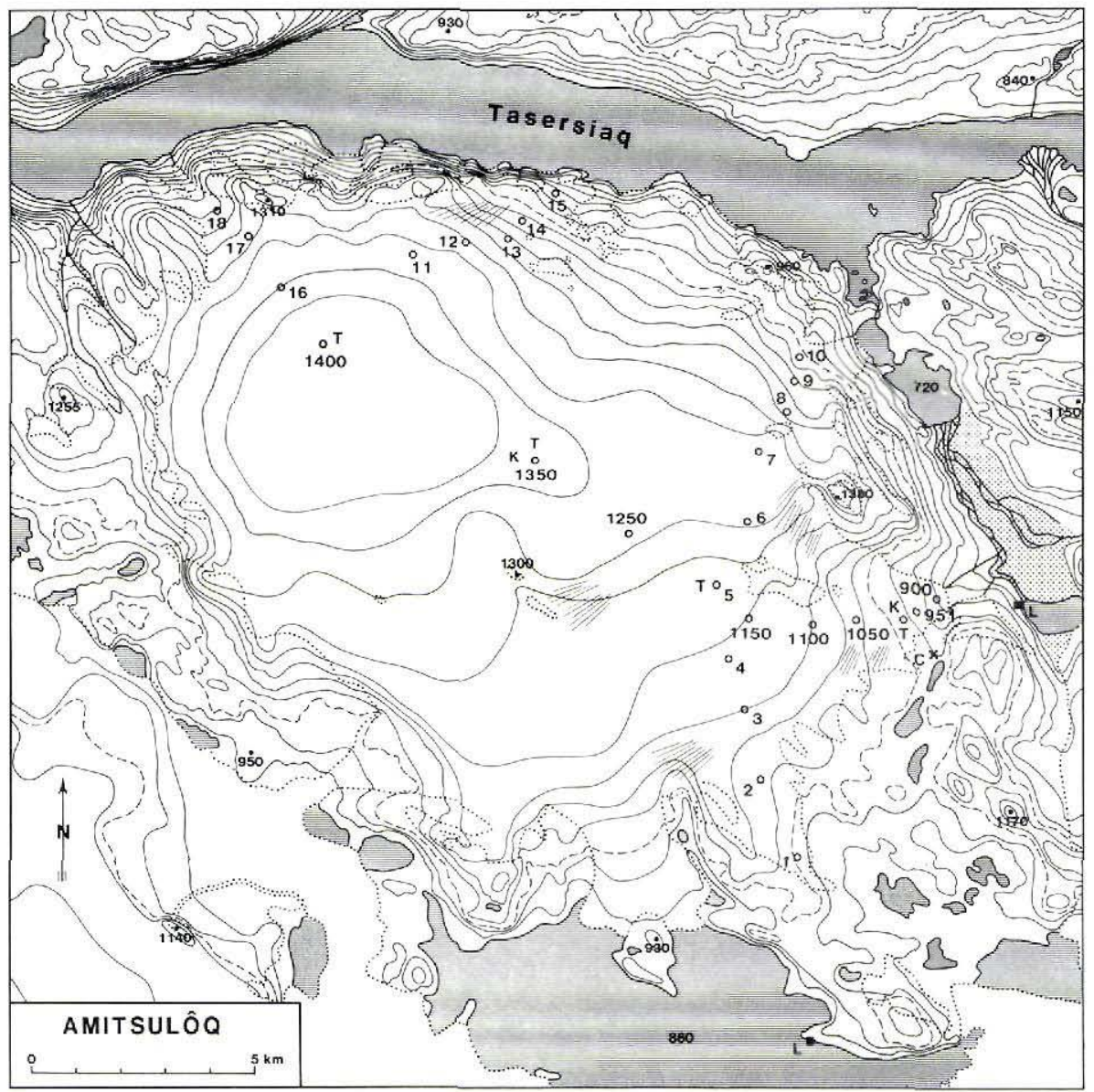

Fig. 1. Map of 'Amitsulôq' ice cap in the Tasersiaq basin. Ablation stakes are numbered. $\mathrm{C}=\mathrm{Base}$ camp. $\mathrm{K}=$ Climate station. $\mathrm{T}=$ Thermistor string. $\mathrm{L}=$ Water stage recorder.

Firn temperature measurements were continued and extended to a depth of $20 \mathrm{~m}$ below surface by emplacing 2 thermistor strings, each with 6 thermistors, using a new portable steam drill. Points with temperature measurements are marked with a $\mathrm{T}$ in fig. 1.

Late in the summer a new row of stakes was set up on the Inland Ice east of the 'Amitsulôq' ice cap. The lowermost stake was erected at $950 \mathrm{~m}$ a.s.l. and the rest at $100 \mathrm{~m}$ elevation intervals up to $1425 \mathrm{~m}$, thus covering the same heights as at 'Amitsulôq' ice cap.

The final glaciological work at the 'Amitsulôq' ice cap was the reading of the whole network of stakes, supplemented by snow density measurements at selected points for the determination of the summer melting. This work was accomplished between 26th August and 4 th September. 


\section{"AMITSULÔQ" ICE CAP}
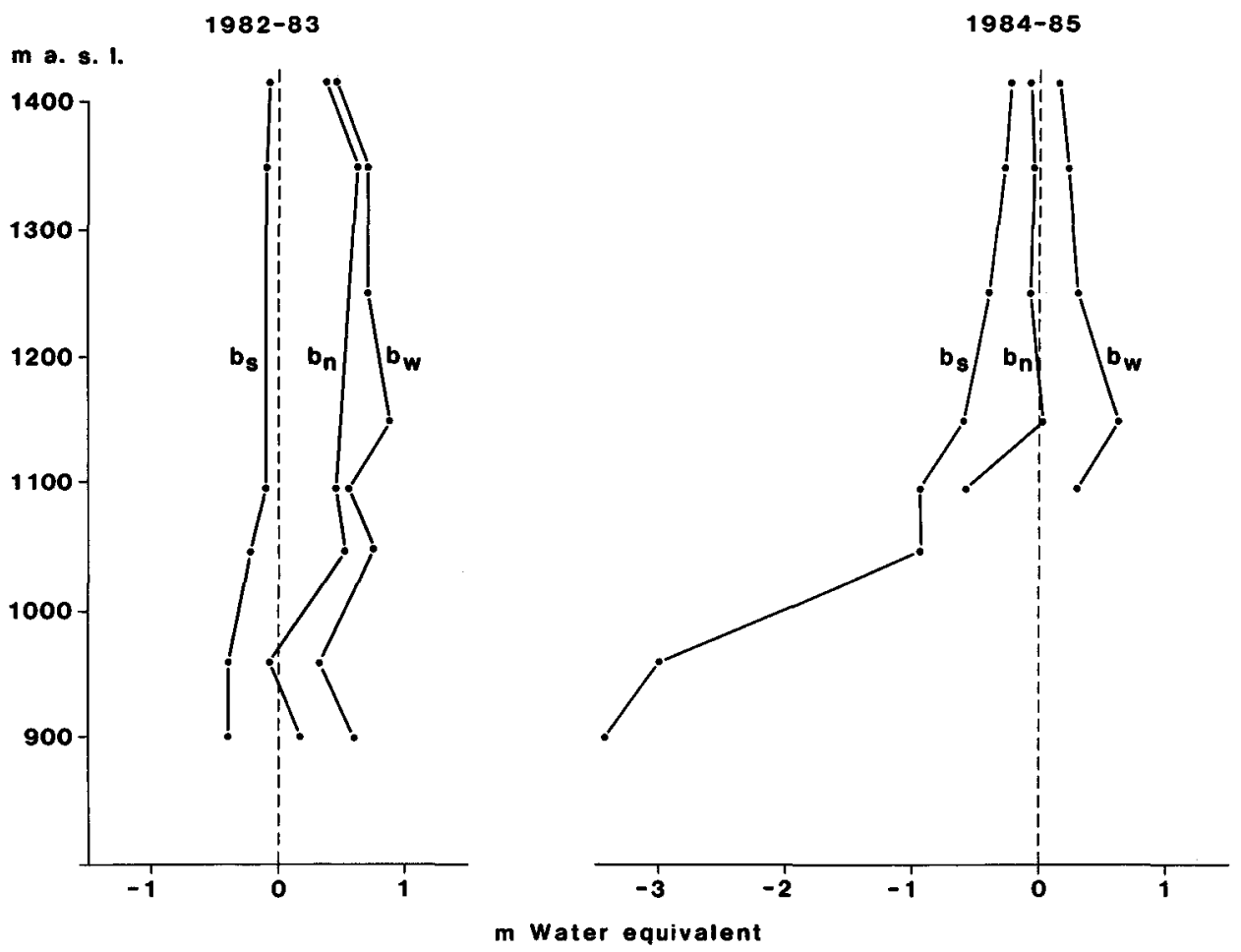

Fig. 2. Mass balance curves for 'Amitsulô' ice cap for the 'extreme' years 1982/83 and 1984/85. $b_{\mathrm{s}}=$ summer balance, $b_{w}=$ winter balance, $b_{n}=$ net balance. Winter and net balances for 1984/85 are incomplete due to melting before winter balance was measured in the spring.

\section{Hydrological field work}

In order to determine if the ice-dammed lake 860 drains under the glacier east of the field station, two water stage recorders were set up during the 1984 field season (marked L on fig. 1). The lake did not drain in 1984 so the recorders were kept running both during the winter and through the 1985 summer field season.

Lake 860 did drain this summer and the surface level dropped $3.25 \mathrm{~m}$ between 17 th and 23rd August. As no increase in discharge was measured by the recorder at the glacier during this time interval, lake 860 must have another under-ice outlet, possibly to the south.

\section{Climatological field work}

During the whole field season four climatological stations were kept running, two on land and two on the ice. The main station is situated at $980 \mathrm{~m}$ a.s.l. by the base camp and observations were made on temperature, humidity, evaporation, precipitation, wind speed, hours of sunshine, global radiation, direction of wind and cloud cover. At the other stations only tem- 

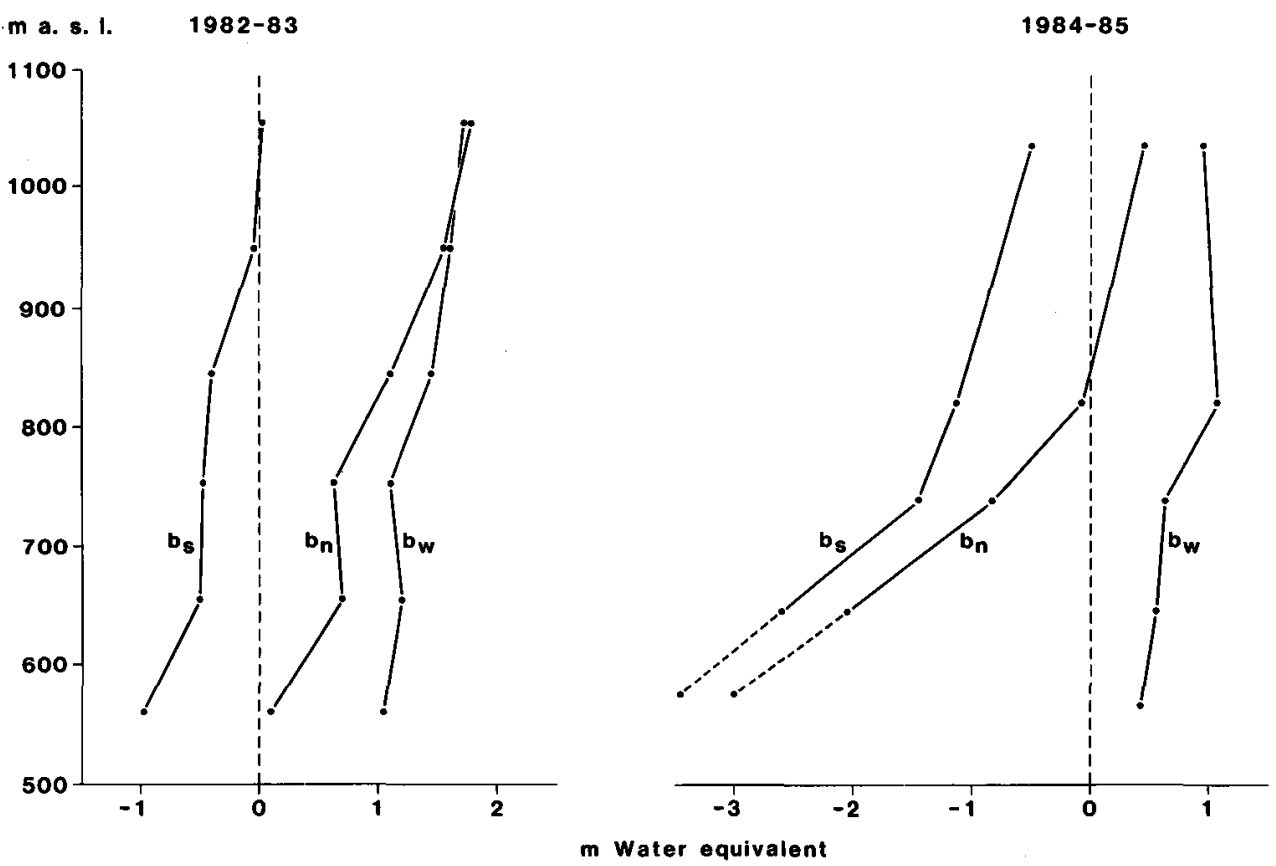

Fig. 3. Mass balance curves for Qapiarfiup sermia for the 'extreme' years 1982/83 and 1984/85. Legends as in fig. 1. Summer balance for the lowest part of glacier has been extrapolated due to loss of the stake.

perature, humidity and precipitation were measured. Two of the remaining stations are situated on 'Amitsulôq' ice cap at 980 and $1350 \mathrm{~m}$ a.s.l. The last station is on land near Tasersiaq glacier about $70 \mathrm{~km}$ west of the base camp and again at $980 \mathrm{~m}$ a.s.l.

\section{Preliminary results}

After two consecutive years with rather high accumulation and low ablation, this year was quite different. A comparison of the mass balance curves for the two 'extreme' years, 1982/83 and 1984/85, for both 'Amitsulôq' ice cap and Qapiarfiup sermia (figs 2 and 3), clearly shows profound changes. At both ice caps the accumulation has been significantly smaller this winter, but the summer ablation is as much as three times greater than in the summer of 1983.

In Table 1 some key figures for the mass balance studies at Qapiarfiuip sermia are given. Of the five balance years measured three have been negative and two positive, with the years 1982/83 and 1984/85 at the opposite extremes. The overall net result has been a surplus of $16.4 \times 10^{6} \mathrm{~m}^{3}$ of water equivalent which is about $80 \%$ of the five years' mean ablation of $20.0 \times 10^{6} \mathrm{~m}^{3}$ (the corresponding accumulation mean is $23.3 \times 10^{6} \mathrm{~m}^{3}$ ). It is interesting to note that while accumulation figures differ by about $155 \%$ the ablation increases by $335 \%$. The dominant factor in the balance is thus the summer ablation. 
Table 1. Mass balance data from Qapiarfiup sermia 1981-1985

\begin{tabular}{lrrrrr}
\hline & $1980 / 81$ & $1981 / 82$ & $1982 / 83$ & $1983 / 84$ & $1984 / 85$ \\
\hline Winter balance & 21.8 & 23.4 & 27.2 & 26.7 & 17.5 \\
Summer balance & 22.7 & 24.5 & 9.1 & 13.1 & 30.7 \\
Net balance & -0.9 & -1.1 & 18.1 & 13.6 & -13.2 \\
\hline
\end{tabular}

Units are $10^{6} \mathrm{~m}^{3}$ of water equivalent

In fig. 4 winter, summer and net balances for the five year period at Qapiarfiup sermia are shown.

A summary of monthly statistics for temperature, precipitation and hours of sunshine at the base camp in the Tasersiaq basin is given in Table 2. Although climatological measurements have been carried out for four summers only, 1982-85, mean summer temperatures have ranged from $-0.3^{\circ} \mathrm{C}$ in 1983 to $2.9^{\circ} \mathrm{C}$ in the years 1982 and 1985 . July is 'normally' the warmest and wettest month while June is the driest. The summer of 1985 had the highest number of hours of sunshine, although it also had the highest precipitation. This seeming contradiction is due to the fact, that the precipitation occurred in fewer events, 29 , in 1985 compared with 46 in 1983 with the next highest precipitation. The climatic influence of the two 'extreme' years on the ablation of 'Amitsulôq' ice cap is clearly demonstrated in the ablation curves $\left(b_{s}\right)$ in fig. 2 .

Resurveying of a few of the stakes on the small outlet glacier from 'Amitsulô' ice cap shows a slight decrease in the yearly rate of movement of $4-5 \%$ compared to last year. The rate of advance of the snout has also dropped from $9.5 \mathrm{~m}$ last year to $6.5 \mathrm{~m}$ this year.

Table 2. Climatological data summary for base camp, Tasersiaq 1982-85

\begin{tabular}{lrrrr}
\hline Monthly mean & June & July & August & Summer \\
\hline Temperature $\left({ }^{\circ} \mathrm{C}\right)$ & & & & \\
1982 & 4.5 & 2.4 & 1.8 & 2.9 \\
1983 & -0.4 & 1.1 & -1.6 & -0.3 \\
1984 & 0.8 & 4.3 & 0.7 & 1.9 \\
1985 & 2.3 & 3.8 & 2.7 & 2.9 \\
Mean & 1.8 & 2.9 & 0.9 & 1.9 \\
& & & & \\
Monthly precipitation $($ mm) & & & \\
1982 & 2 & 46 & 10 & 58 \\
1983 & 16 & 39 & 21 & 77 \\
1984 & 1 & 38 & 14 & 52 \\
1985 & 45 & 16 & 26 & 87 \\
Mean & 16 & 35 & 18 & 65 \\
Monthly hours of sunshine & & & \\
1982 & 212 & 138 & 264 & 614 \\
1983 & 209 & 202 & 116 & 527 \\
1984 & 260 & 266 & 64 & 590 \\
1985 & 268 & 317 & 272 & 857 \\
Mean & 237 & 231 & 179 & 647 \\
\hline
\end{tabular}




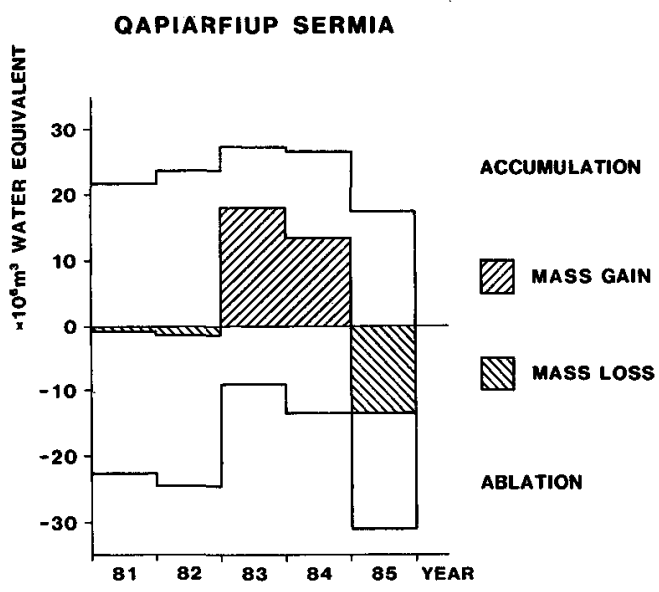

Fig. 4. Histogram of mass balance data for Qapiarfiup sermia for the years 1981 to 1985 .

\title{
References
}

Olesen, O. B. 1982: Establishment of a new survey station at Tasersiaq. Rapp. Grønlands geol. Unders. 110, 86-88.

Olesen, O. B. 1985: Glaciological investigations in 1984 at Tasersiaq and Qapiarfiup sermia, West Greenland. Rapp. Grønlands. geol. Unders. 125, 104-107.

Olesen, O. B. \& Andreasen, J. O. 1983: Glaciological, glacier-hydrological and climatological investigations around $66^{\circ} \mathrm{N}$, West Greenland. Rapp. Grønlands geol. Unders. 115, 107-111.

\section{Exceptionally high ablation in 1985 at Qamanârssûp sermia, West Greenland}

\author{
Roger J. Braithwaite
}

As part of the GGU programme of hydropower investigations in West Greenland, climatological and glaciological measurements were continued at Qamanârssûp sermia (inventory number $1 \mathrm{CH} 21002$ ) in 1985. The field programme was generally the same as in previous years (see Braithwaite, 1985a, b). The station was established in August 1979 so that records for six complete summers 1980-1985 are now available. Detailed summaries of results up to 1984 are given in Braithwaite $(1985 \mathrm{a}, \mathrm{b})$ while the latest results will be presented in a Gletscher-hydrologiske Meddelelser in spring 1986.

\section{Climatological and glaciological situation}

When the field party arrived at Qamanârssûp sermia in early June it was obvious that the 1984/85 winter had been an unusual one. There was no winter snow cover at the base camp 